\title{
MODEL PENGEMBANGAN PARADIGMA INTEGRASI ILMU DI UNIVERSITAS ISLAM NEGERI SUNAN KALIJAGA YOGYAKARTA DAN UNIVERSITAS ISLAM NEGERI MAULANA MALIK IBRAHIM MALANG
}

\author{
Arbi, Imam Hanafi, Munzir Hitami, Helmiati \\ Fakultas Tarbiyah dan Keguruan UIN Suska Riau, Institute for Southeast Asian \\ Islamic Studies (ISAIS) UIN Suska Riau, Program Pascasarjana UIN Suska Riau, \\ Program Pascasarjana UIN Suska Riau \\ E-Mail: arbi@uin-suska.ac.id, Imam.hanafi@ uin-suska.ac.id,mzr.hitami@gmail.com, \\ emikahar@yahoo.com
}

\begin{abstract}
Abstrak: Mencuatnya perbincangan persoalan integrasi ilmu ke permukaan, sebenarnya merupakan suatu upaya untuk mencermati dinamika kehidupan dan keilmuan yang dikotomik di dunia Islam. Upaya untuk mengintegrasikan dan menginterkoneksikan berbagai keilmuan Islam dengan sains adalah daya upaya dan sekaligus sebagai jawaban mendesak atas kelemahan dan kekurangan di kalangan umat Islam dibandingkan paradigma ilmu Barat. Telah berabad-abad kaum muslimin terpenjara dalam pemahaman keagamaan yang sempit dan tidak rasional. Seakan-akan mengkaji alam semesta bukan merupakan perbuatan agama. Terjadi pemisahan secara tegas antara urusan dunia dengan akhirat, antara sains dengan agama, antara ilmuwan dengan ulama. Konsekuensinya, dunia Islam tertinggal jauh dari kemajuan sains Barat. Sadar akan keterbatasan dari terpaan dan tamparan sains, ilmu pengetahuan dan teknologi Barat, PTAI Se-Indonesia berbenah diri, melakukan perombakan dan perubahan serius. Perubahan STAIN menjadi IAIN dan konversi IAIN menjadi UIN masih menyisakan problema besar, rumit dan pelik, terutama terletak pada persoalan pengembangan paradigma integrasi ilmu, pilar spritualitas dan model implementasinya. Model pengembangan paradigma integrasi ilmu yang dikembangkan di UIN Suka Yogyakarta terkonsentrasi pada simbol jaring laba-laba dan UIN Maliki Malang bersimbolkan pohon ilmu.
\end{abstract}

Kata Kunci: Integrasi; Interkoneksi; Sains; Ilmu-ilmu Islam; Paradigma

\section{PENDAHULUAN}

Proses pembelajaran dalam pendidikan Islam, tidak hanya menitikberatkan pada talim (teaching), yang tertuju hanya pada aspek "intelektual", yang bersifat transformation of knowledge untuk intelectual quotient semata, melainkan harus sebanding dan sesanding dengan ta'dib (education) sebagai wahana transformation of value, yang mengandung makna pengendalian dan pengelola emosi (emosional quotion). Hal ini merupakan aspek terpenting yang mesti dijadikan pilar pendidikan yakni spiritual itu sendiri. ${ }^{1}$ Pilar utama ini yang dapat membina dan membentuk diri sebagai manusia, karena pendidikanlah yang memanusiakan manusia sebagai manusia. $^{2}$

Pilar spiritual yang mengandung dan mengundang tunjuk ajar bagi manusia, agar dapat melakukan penghayatan atas dirinya sebagai hamba ('abdullah), yang

1 Istilah spiritual merupakan derivasi dari kata spirit, yang berarti sesuatu yang berkaitan dengan ruh, jiwa, atau sesuatu Yang Maha Pencipta dan Maha Kuasa, sebagaimana keyakinan yang dimiliki oleh seseorang. Lihat Oxford Advanced Learners's Dictionary. (Oxford Universuity Press. 1995), hlm. 1145-1146

2 Abd.Rachman Assegaf, Studi Islam Kontekstual, (Gema Media,Yogyakarta, 2005)., hlm. 57. 
kelahirannya memang membawa misi untuk mengabdi dan beribadah kepada Allah semata-mata. Secara normatif, manusia adalah hamba Allah sekaligus sebagai pengemban misi kekhalifahan. Dalam konteks ini, maka relasi manusia dengan Tuhan, merupakan hubungan kehambaan ('ubudiyyah). Pengingkaran atas relasi ini, berarti pengkaran akan eksistensi Tuhan. Sebagai hamba, manusia tidak memiliki kemampuan untuk menolak atau mempersoalkan ketentuan ini. Seorang hamba atau $a b d$, dapat disebut sholeh atau baik, ketika ia mampu mengekspresikan diri dengan segala ketundukan dan ketaatan pada tuhannya dan meyakini bahwa apa yang telah ditetapkan oleh Tuhan adalah sesuatu yang terbaik untuk dirinya. ${ }^{3}$ Selain itu, manusia juga mengemban misi "khalifatullah fil ardh", suatu amanah untuk memberikan rasa tenang dan bahagia bagi semua makhluq hidup, menebarkan suasana aman (yang semakna dengan kata iman) dan suasana damai bagi seluruh makhluk Tuhan lainnya di alam semesta ini. ${ }^{4}$ Oleh karena itu, proses pembelajaran dalam pendidikan Islam, mengharuskan adanya misi 'abdullah sekaligus sebagai khalifatullah fil ardh ini.

Secara paradigmatik, proses pembelajaran selama ini hanyalah ritual transfer of knowledge, pemindahan utuh-utuh pengetahuan guru kepada peserta didik. Pandangan ini, dalam dunia pendidikan secara umum, sudah bergeser, dimana transfer pengetahuan melalui proses rekonstruksi atau proses pembangunan dan penemuan pengetahuan atau pemikiran dari dalam diri sendiri. Karena itu, pendidikan Islam perlu merubah cara pandang dalam melakukan transformasi pengetahuan. Peserta didik tidak lagi dianggap sebagai obyek pembelajaran, namun sebagai

\footnotetext{
3 Daud Rasyid, Islam dalam Berbagai Dimensi, (Bandung: Gema Insani, 1998)., hlm. 66.

4 Hadari Nawawi, Hakikat Manusia menurut Islam, (Bandung: Gema Risalah, 1992)., hlm. 217.
}

subyek pembelajaran. Sehingga peserta didik mandiri dalam mengelola pikiran secara terarah. Peserta didik dianggap memiliki kemampuan untuk mengelola kemadirian dirinya sendiri, terutama berkaitan dengan perkembangan ilmu pengetahuan dan teknologi informasi yang berkembang pesaat saat ini.

Namun demikian, yang terjadi di lembaga-lembaga pendidikan Islam adalah sebuah "ironi" dalam lembaga Pendidikan Tinggi Keagamaan Islam (PTKI) di negeri kita saat ini, karena hakikat agama Islam yang sebenarnya tidak memisahkan antara kehidupan zhahir dan bathin, antara dunia dan akhirat, antara ilmu-ilmu agama dan ilmuilmu sains. Wacana tentang konsepsi ilmu dalam pendidikan Islam, merupakan perdebatan yang sudah panjang. Karena ada asumsi dikalangan umat Islam bahwa sebab terjadinya kemunduran dalam dunia Islam, dilatarbelakangi oleh adanya dikotomi ilmu dan rapuhnya umat Islam akan keimanan dan kerusakan hati oleh filsafat dan ilmu pengetahuan. ${ }^{5}$

Dari berbagai kajian tentang keberadaanPendidikan TinggiKeagamaan Islam (PTKI) dalam memenuhi hakikat dan tujuan Pendidikan Islam yang bersifat universal ditemukan beberapa masalah, diantara permasalahan besar yang dihadapi dan dialami oleh lembaga PTKI, baik negeri ataupun swasta adalah :

Pertama, Terjadinya perubahan model pendidikan pada Madrasah Aliyah, yang semula banyak mata pelajaran agama, namun belakangan sudah mulai bergeser lebih banyak mata pelajaran umum. Sebagaimana pendapat Abudin Nata yang

5 Adanya hegemoni peradaban Barat atas ilmu pengetahuan sains telah membawa implikasi pada lemahnya peradaban muslim pada masa itu, hingga hari ini, terutama di bidang epistemologi. Munculnya istilah westernisasi ilmu itu sendiri, sesungguhnya merupakan dampak dari hegemoni epistemologi Barat tersebut, yang justru menghasilkan kebingungan dan skeptisisme. Lihat Syed Muhammad Naquib al-Attas, Islam and Secularism, (Kuala Lumpur: ISTAC, Edisi Kedua, 1993), hlm. 133-135. 
menyatakan bahwa pada masa-masa awal berdiri dan berkembangnya Madrasah Aliyah, lebih banyak berorientasi pada pembelajaran keagamaan (Islam) dari pada mata pelajaran umum, namun pada proses selanjutnya, Madrasah Aliyah justru mulai berbalik, lebih banyak mempelajari umum dari pada agama, sehingga muncul istilah "sekolah umum bernuansa agama". Mata pelajaran umum lebih banyak dibanding sebelumnya. Oleh sebab itu, lulusan Madrasah Aliyah memiliki kecenderungan yang cukup besar untuk masuk program studi umum. Jika STAIN/IAIN hanya menyediakan jurusan agama saja dan tidak segera berbenah, peminatnya akan semakin berkurang. ${ }^{6}$

Kedua, STAIN/IAIN dianggap sebagai lembaga dakwah.Salah satu permasalahan yang muncul sebelum STAIN/IAIN berubah menjadi UIN, adanya persepsi yang berkembang di masyarakat bahwa STAIN/IAIN adalah lembaga dakwah dan bukan lembaga akademik. Hal ini disebabkan sebagian besar alumni lebih memainkan peran sebagai ulama daripada ilmuwan. Hal ini sebagaimana disebutkan oleh Azyumardi Azra bahwa Perguruan Tinggi Keagamaan Islam saat ini, cenderung berkontribusi pada area dakwah saja, tetapi belum berkontribusi banyak pada pengembangan wilayah akademis, misalnya pada bidang riset dan pada masyarakat Indonesia pada umumnya. ${ }^{7}$

Ketiga, Kuatnya arus Ilmu Agama dan Umum di masa lalu yang dikotomik. Adanya pemahaman yang dikotomik antara ilmu agama dan ilmu umum, menjadi persoalan serius dalam dunia Islam. Bahkan ada anggapan keduanya

6 Abuddin Nata, Manajemen Pendidikan, Mengatasi Kelemahan Pendidikan Islam di Indonesia, (Jakarta: Kencana Prenada Media Group, cet. IV. 2013)., hlm. 210

7 Imam Suprayogo, Perubahan Pendidikan Tinggi Islam; Refleksi Perubahan IAIN/STAIN menjadi UIN. (Malang: UIN Malang Press. 2008)., hlm. 11. sulituntuk disatukan.Implikasinya adalah berdirinya lembaga-lembaga pendidikan umum dengan megah, sementara lembaga Pendidikan Islam masih terus merangkak memperjuangkan eksistensinya secara kuantitatif maupun kualitatif. Wajarlah jika kemudian lembaga Pendidikan Islam belum dianggap sejajar dengan lembaga pendidikan umum. ${ }^{8}$ Oleh karena STAIN/IAIN adalah lembaga pendidikan agama Islam, STAIN/IAIN tidak bisa mengembangkan fakultas sebagaimana yang diinginkan masyarakat. Masyarakat menuntut STAIN/IAIN memberikan tawaran fakultas baru. Namun STAIN/ IAIN mengalami kemandegan akademik karena kemandegan tradisi keilmuan. Kemandegan itu dikarenakan fakultasfakultas keagamaan yang ada terikat pada doktrin-doktrin yang ada. ${ }^{9}$

Keempat, STAIN/IAIN dianggap tidak mampu merespon perkembangan zaman. Pendidikan Tinggi Keagamaan Islam dianggap tidak mampu melakukan respon dan tidak marketable dalam persaingan global. Hal ini, bisa jadi karena begitu kuatnya pendidikan Tinggi Umum yang dimanjakan oleh pemerintah. Selain itu, proses pembelajaran di STAIN/IAIN tidak menawarkan metode pendekatan yang sesuai dengan kebutuhan masyarakat pada zamannya. Kurikulum yang berjalan selama ini di STAIN/IAIN juga dinilai belum bisa mengimbangi laju perkembangan ilmu pengetahuan dan Teknologi dan perubahan masyarakat yang semakin dinamis dan kompleks. ${ }^{10}$ Akibatnya, banyak lulusan STAIN/IAIN yang menjadi pengangguran. Hal ini sebagaimana disampaikan oleh Prof. A. Chotib Qudwain, bahwa ada wajah penyesalan telah kuliah di IAIN Jambi,

8 Muljono Damopolii, Potret Pendidikan Islam: Perspektif Pembaruan Pemikiran Dan Gerakan Islam Indonesia Kontemporer. (Jurnal Lentera Pendidikan, Edisi X, no. 1, Juni 2007)., hlm. 56.

9 Abdullah Idi dan Toto Suharto, Revitalisasi Pendidikan Islam. Yogyakarta: Tiara Wacana. 2006), hlm. 79.

$10 \quad$ I b $\boldsymbol{i}$ d., hlm. 195. 
ketia beliau memandang wajah-wajah para alumni. ${ }^{11}$

Kelima, STAIN/IAIN dianggap tidak menyelenggarakan pendidikan secara professional. Perubahan dan semakin membaiknya tingkat ekonomi dan kesejahteraan masyarakat, menyebabkan masyarakat semakin kuat untuk memiliki kualitas hidup yang baik pula, termasuk kualitas pendidikan. Oleh karena itu, masyarakat juga menginginkan penyelenggaraan pendidikan yang berkualitas. STAIN/IAIN dianggap sebagai perguruan tinggi kelas dua. Jika STAIN/IAIN tidak berbenah, peminatnya akan semakin berkurang. ${ }^{12}$

Berdasarkan fenomena yang demikian rumit dan pelik berkenaan dengan usaha dan tindaklanjut dari konsekuensi perubahan STAIN/IAIN menjadi UIN, peneliti menjadikan UIN Sunan Kalijaga Yogyakarta dan UIN Maliki Malang sebagai rujukan dan target kajian. Pokok masalah yang akan dijawab adalah model pengembangan paradigma integrasi antara sains dan Islam serta implementasinya di Universitas Islam Negeri Sunan Kalijaga Yogyakarta dan di Universitas Islam Negeri Maliki Malang.

\section{KERANGKA TEORI}

\section{Integrasi Ilmu sebagai Paradigma Keilmuan}

Secara bahasa, istilah paradigma merupakan gabungan dari kata para dan diegma. Dalam bahasa Yunani, kata para berarti di sebelah atau di samping, sementara diegma, bermakna teladan, ideal, model atau arketif. Adapun secara istilah, paradigma merupakan sebuah cara pandang yang dipakai oleh seseorang dalam memahami dan melihat alam semseta, yang berupa sebuah

\footnotetext{
11 Marwan Saridjo. Pendidikan Islam dari Masa ke Masa: Tinjauan Kebijakan Publik terhadap Pendidikan Islam di Indonesia, (Bogor: Yayasan Ngali Aksara dan alManar Press, Cet. II. 2011). hlm. 197.

12 Abudi Nata, Op.cit ., hlm. 68
}

deskripsi atau perspektif umum tentang metode atau teknik untuk menjelaskan kompleksitas problematika alam semesta. Oleh karena itu, dalam sebuah paradigma, terhimpun tiga elemen pokok; metodologi, epistemologi, dan ontologi. ${ }^{13}$

Dengan demikian, integrasi berarti proses menyatukan untuk menjadi satu kesatuan konsep yang utuh, ${ }^{14}$ atau bisa juga diartikan dengan proses memadukan nila-nilai tertentu dalam sebuah ilmu pengetahuan terhadap konsep yang lain yang berbeda, sehingga menjadi keterpaduan dan tidak bisa dipisahkan. M. Amir memberikan pendapat bahwa integrasi keilmuan yaitu integration of science means the recognition that alltrue knowledge is from Allah and all sciences should be treated with equal respect whether it is scientific or revealed. ${ }^{15}$ Dengan demikian, integrasi keilmuan berarti sebuah upaya untuk menyatukan atau menggabungkan keilmuan yang memberi ruang lingkup pada aktifitas nalar manusia (sekularisme) dan juga menyediakan keleluasaan pada Tuhan dan Wahyu-Nya. ${ }^{16}$ Istilah lainya adalah "Islamisasi Ilmu Pengetahuan". ${ }^{17}$ Dan ini didasakan pada asumsi akan

13 https://pengertiandefinisi.com/pengertian-paradigma/

14 W.J.S. Poerdowasminto, Konsosrsium Bahasa Indonesia, (Jakarta : Balai Pustaka, 1986), hlm. 384.

15 M. Amir Ali, Removing The Dichotomy of Science : ANecessity for The Growth of Muslim s. future Islam "A Journal of Future Ideology that Shapes Today The World Tomorrow. http"//www. futureislam. com/ 20050301/insight.

16 Kuntowijoyo, Islam Sebagai Ilmu Epistimologi, Metodologi dan Etika, (Yogyakarta : Tiara Wacana, 2006), hlm. 55.

17 Dalam jagad keilmuan, diskursus tentang "islamisasi ilmu pengetahuan" muncul pertama sekali melalui sebuah buku yang berjudul The Encounter of Man and Nature, karya Seyyed Hoessein Nasr. Wacana ini kemudian diteruskan dan didiskusikan lebih mendalam dan serius pada tahun 1977, yaitu pada konferensi Internasional I tentang pendidikan Muslim di Mekkah, kemudian dilanjutkan pada tahun 1980, yaitu pada konferensi Internasional ke II di Islamabad Pakistan. Pada konferensi itulah, Syed Naquib alAttas dan Ismail Raji al-Faruqi, mengemukakan akan pentingnya merekonstruksi sebuah epistemologi Islam. Lihat Syamsul Arifin dkk, Spiritualisasi Islam dan Peradaban Masa Depan, (Yogyakarta: SIPRESS, 1996), hal. 77 
adanya kejayaan ilmu pengetahuan dan sains yang telah berkembang dengan baik pada masa peradaban Islam, dimana ilmu dan agama telah terintegrated. ${ }^{18}$

Diantara para tokoh muslim yang terlibat aktif dalam diskusi tentang wacana tersebut diantaranya adalah Seyyed Hossein Nasr, Naquib al-Attas, Isma'il Al-Faruqi, dan Ziauddin Sardar. Jika Naquib al-Attas menggunakan istilah "dewesternisasi ilmu" untuk integrasi ilmunya, maka Isma'il Raji AlFaruqi mempertengahkan dengan istilah islamisasi ilmu; Sementara Ziauddin Sardar mendorong konsep "sains Islam kontemporer". ${ }^{19}$

Dalam perspektif Nasr, sains Islami dapat dibangun jika ia melalui intelek (intelect) berasal dari Illahiyah. Kedudukan intelek ini berada dalam hati manusia dan besifat ilahiyah. Sementara pengetahuan diperoleh dari akal semata, dan akal bukanlah bagian dari intelek, maka ia tidak dapat dijadikan sebagai sains Islam. ${ }^{20}$ Sementara Sardar, meyakini bahwa proses islamisasi ilmu pengetahuan perlu berangkat dari upaya membangun epistemologi islam secara original, sehingga betul-betul menghasilkan sistem pengetahuan yang dikontruksi diatas asas dan fondasi ajaran atau nilai-nilai Islam.

Gagasan dandiskursusislamisasiilmu tersebut, tidaklah berjalan sempuurna sebagaimana yang diharapkan para pelopornya. Beberapa ilmuan muslim banyak menolak gagasan tersebut. Muhammad Arkoun misalnya, seorang pemikir muslim handal di era Modern ini, menyatakan tidak sepakat jika ilmu harus diislamkan. Beliau menegaskan bahwa

18 Zainal Abidin Bagir, dkk., (Eds)., Integrasi Ilmu dan Agama: Intrepretasi dan Aksi. (Bandung: PT Mizan Pustaka Kerjasama dengan UGM dan Suka Press Yogyakarta, 2005), hlm. 20.

19 Taufik Abdullah dkk, (ed)., Ensiklopedi Tematis Dunia Islam, jilid ke-6, (Jakarta: Ichtiar Baru Van Hoeve, 2002), hal. 145.

20 Zainal Habib, Islamisasi Sains. (Malang, UIN Malang Press, 2007), hlm. 23 usaha untuk menjadikan agama sebagai sebuah ilmu, maka akan menggeser ilmu menjadi agama. Ilmu pengetahuan diperoleh melalui kontribusi para ilmuan, yang hal itu bisa salah dan bisa pula benar. Tidak mungkin ilmu itu sakral, jika ternyata ia harus tunduk kepada kebenaran teori lain yang lebih valid kebenarannya. ${ }^{21}$

\section{HASIL DAN PEMBAHASAN \\ Metamorfosa Integrasi Ilmu; Konversi STAIN/IAIN Menjadi UIN}

Perubahan STAIN/IAIN menuju UIN, dalam perspektif manajemen perubahan, adalah perubahan besar-besaran atau yang disebut dengan dramatic change. Oleh karena perubahan STAIN/IAIN menjadi UIN adalah perubahan besar, maka diperlukan landasan-landasan yang menjadi tumpuan perubahan tersebut sebagai Landasan Yuridis Dasar hukum perubahan STAIN/IAIN menjadi UIN, diantaranya adalah landasan filosofis.

Secara filosofis, bahwa dalam Islam, ilmu itu terbagi menjadi dua, yaitu perennial knowledge (ilmu agama) dan accquined knowledge (ilmu umum). Keduanya dalam konferensi Internasional di Mekkah maupun di Islamabad, secara konseptual telah disusun dengan rinci bagaimana implentasinya mulai dari tingkat pendidikan dasar, menengah, hingga pendidikan di perguruan tinggi. Penyusunan subjek-subjek tersebut telah dirancang berbagai ilmu-ilmu yang mesti dikuasai oleh setiap muslim. Namun aplikasinya tentu tidak lepas dari tujuan institusional dari suatu lembaga pendidikan tertentu. Dari rumusanrumusan tersebut pada prinsipnya untuk dapat mengaktualisasikannya terutama

21 Kritik lain dari Arkoun bahwa jika upaya islamisasi ilmu penegetahuan merupakan sebuah langkah yang salah bagi umat Islam. Karena justru akan menggiring umat Islam pada asumsi bahwa Islam hanya semata-mata sebaga ideologi. Lihat Juan E. Campo, Ensyclopedia of Islam. (New York: An Imprint of Infobase Publishing, 2009), hlm. 61. 
atas pembagian ilmu ke dalam dua poin besar universitaslah sarana yang tepat untuk menampung keinginan itu. ${ }^{22}$

Lebih jauh, dasar penting metamorfosa kelembagaan dari IAIN ke UIN, sebagaimana juga telah penulsi kemukakan dalam latar belakang di atas, adalah sebagai berikut; Pertama, adanya keinginan kuat untuk melakukan pemaduan atau penyatuan antara disiplin ilmu-ilmu agama dengan disiplin ilmuilmu umum (perennial knowledge dengan accquined knowledge). Tujuannya adalah agarkeduanya tidak lagidianggapberjalan secara dikotomik, melainkan menyatu, berjalin-kelindan dan seiring-jalan. Kedua, karena perubahan status madrasah yang semula merupakan lembaga pendidikan yang memiliki konsentrasi mempelajari ilmu-ilmu agama, justru berubah menjadi sekolah yang "bercirikan Islam". Artinya, madrasah tidak lagi menyiapkan lulusannya untuk mempelajari keislaman an sich, namun lebih banyak mempelajari ilmu-ilmu umum. Sehingga, banyak lulusan Madrasah Aliyah kemudian memilih universitas-universitas umum. Dan Ketiga, jika perubahan institut ke universitas dapat terwujud, maka akan membuka peluang yang luas bagi semua lulusan UIN, sehingga mereka akan semakin memperoleh kesempatan untuk melakukan mobilitas vertikal dan memiliki peluang yang lebih beragam dalam memilih lapangan kerja. ${ }^{23}$

Sementara dalam pandangan Imam Suprayogo, persoalan penting yang selama ini muncul adalah bahwa gegap gempita kemajuan IPTEK saat ini, justru berasal dari kontribusi pendidikan tinggi umum, bukan dari lembaga-lembaga pendidikan tinggi yang memiliki misi "Islam". Karena dapat dimaklumi bahwa lembaga-lembaga pendidikan tinggi Islam, masih bergelut dengan ilmu-lmu

\footnotetext{
22 Haidar Putra Daulay, Sejarah Pertumbuhan dan Pembaharuan Pendidikan di Indonesia, (Jakarta: Kencana, 2009), hlm. 146.

23 I b i d., hlm. 129-130.
}

syari'ah semata, seperti adab, syari'ah, ushuludin, dakwah, dan tarbiyah. Jika perguruan tinggi Islam, masih sibuk dengan urusan agamanya saja, maka jangan heran jika kemudian Islam tidak memiliki konsep universalitasnya. ${ }^{24}$

Dari beberapa argumentasi di atas, maka perjuangan beberapa pendidikan Tinggi Keagamaan Islam, untuk berubah dari Sekolah Tinggi atau Intitute menjadi Universitas, menjadi cita-cita bersama setiap STAIN atau IAIN. Mulai tahun 2002, cita-cita itu mulai menuai titik terang, ketika UIN Syahid Jakarta, menerima mandate-nya untuk bermetamorfosa dari IAIN Syahid menjadi UIN Syahid, berdasarkan surat keputusan (SK) Presiden RI No. 031 tanggal 20 Mei 2002. UIN Syahid sendiri, telah melakukan perjuangan perjuangan panjang untuk melakukan metamorfosa kelembagaan ini, yaitu dimulai sejak masa Prof. Harun Nasution sebagai Direktur Pascasarjana, dan konon sudah mendapat restu dari Tarmizi Taher sebagai Menteri Agama pada masa itu. Sejak itu lah, maka mereka mengawalinya dengan membuka jurusan dan program studi umum. ${ }^{25}$

Kesuksesan UIN Syahid dalam melakukan perubahan kelembagaan tersebut, meningkatkan motivasi bagi IAIN lainnya untuk berubah. Kali ini, IAIN Yogyakarta memperoleh restu untuk beralih status menjadi Universitas Islam Negeri (UIN), ${ }^{26}$ bersama-sama dengan STAIN Malang menjadi UIN Malang. Restu itu diperoleh berdasarkan

24 Imam Suprayogo, Universitas Islam Unggul, (Malang: UIN Malang Press, 2009), hlm. 46 - 47.

25 Haidar Putra Daulay, Pemberdayaan Pendidikan Islam di Indonesia, (Jakarta: Rineka Cipta, 2009)., hlm. 70 .

26 SK Presiden RI Nomo 50 Tahun 2004 Tanggal 21 Juni 2004. berisi tentang Perubahan IAIN Sunan Kalijaga Yogyakarta menjadi UIN Sunan Kalijaga Yogyakarta dan STAIN Malang Menjadi UIN Malang. Pasal 1 ayat. (1) Mengubah status Institut Agama Islam Negeri Sunan Kalijaga Yogyakarta menjadi Universitas Islam Negeri Sunan Kalijaga Yogyakarta; (2) Mengubah status Sekolah Tinggi Agama Islam Negeri Malang menjadi Universitas Islam Negeri Malang. 
SK Presiden Nomor 50 tanggal 21 Juni 2004. Berdasarkan SK Presiden RI inilah, kemudian atas nama Presiden, Prof. Malik Fadjar, yang pada waktu itu menjabat sebagai Menko Kesra, meresmikan UIN Malang sebagai lembaga pendidikan Tinggi Keagamaan Islam, yang mengemban amanah untuk menyelenggarakan program pendidikan yang integratif, yakni pemaduan ilmuilmu agama Islam dengan disiplin ilmuilmu umum. ${ }^{27}$

Maraknya keinginan konversi ini diharapkan jangan hanya sebagai alat politis atau sarana mencari keuntungan yang sebesar-besar oleh pihak- pihak tertentu, karena sikap demikian sangat tidak etis. Namun hendaklah tetap berada pada jalur untuk pengembangan keilmuan sebagai yang sudah disebutkan di atas. Adapun urgensi konversi ini sebagaimana Moh. Raqib sebutkan bahwa hendaklah pada konsep dasar, dan secara konkret dapat dikemukakan gagasangagasan pengembagan keilmuan di Pendidikan Tinggi Keagamaan Islam, harus tetap berorientasi masa depan dalam rangka menjemput era globalisasi. Lebih lanjut, Raqib menyebutkan bahwa PTKI haruslah mengemban beberapa hal sebagai berikut:

a. Menyempurnakan pembidangan ilmu di PTI/UIN yang mencakup tiga pilar: Aqidah, Muamalah, dan Akhlak al-Karimah. Sejumlah hierarki vertikal ilmu sebagian dapat ditarik ke atas seperti studi humaniora sampai aqidah, studi teknologi dan profesional ke mu'amalah, dan studistudi ilmu sosial ke bidang etikamoral (akhlak al-karimah).

b. Diperlukan pendalaman Studi Islam dan bahasas asing (Arab-Inggris)

$\overline{27}$ Laily Nur Arifa, "PERUBAHAN STAIN/ IAIN MENJADI UIN SEBAGAI BENTUK PENGEMBANGAN PENDIDIKAN TINGGI ISLAM (Contoh Kasus Perubahan STAIN menjadi UIN Malang Perspektif Manajemen Perubahan Kurt Lewin)" dalam Jurnal Vicratina Vol 01, No 2 (2017), hlm. 34 - 35. bagi mahasiswa sebelum mereka masuk ke fakultas atau jurusan tertentu. Proses pembelajaran dengan menggunakan bahasa asing merupakan upaya yang patut dilakukan mengingat sarjana saat ini dituntut unuk mampu memahami dan mengkomunikaskan ilmu dalam wilayah yang tidak terbatas dengan menggunakan bahasa internasional.

c. Peningkatan SDM pengajar atau dosen dengan cara menempuh studi lanjut. Selain itu juga meningkatkan tradisi membaca yang tinggi, yang diikuti dengan menulis karya ilmiah.

d. Untuk memenuhi kebutuhan pasar, perlu dilakukan penelitian tentang tuntutan stake holders dan tidak segan-segan untuk mengoreksi ulang program yang ada.

e. Dari sisi politik dan hukum diperlukan pendekatan khusus yang komprehensif agar muncul kebijakan politik dan produk hukum yang berpihak pada pengembangan PTI ke depan. Proses pengakuan pada alumni PTI secara legal formal harus segera diselesaikan dengan pendekatan politik hukum agar tidak ada kesan bahwa PTI merupakan perguruan tinggi yang hanya mempersiapkan sarjana atau tenaga ahli di bidang ilmu-ilmu agama saja. ${ }^{28}$

Dengan demikian, apabila STAIN hanya mengkaji dan menekuni satu bidang keilmuan semata, dan IAIN hanya memberikan ruang gerak pada bidangbidang keilmuan yang lebih beragam, namun masih terbatas pada lingkup kajian Islam, maka dengan melakukan metamorfosa ke UIN, agama Islam akan nampak lebih universal. Artinya, konsep Islam yang universal itu, akan mewujud dengan adanya universitas. Perubahan

28 Moh. Raqib, Ilmu Pendidikan Islam, Pengembangan Pendidikan Integratif di Sekolah, Keluarga, dan Masyarakat, (Yokyakarta: LKiS, 2009), hlm. 167-168. 
ini juga sebagai bentuk upaya untuk mewujudkan proses integrasi antara ilmu-ilmu keagamaan (Islam) dengan ilmu-ilmu umum demi mewujudkan kembali peradaban Islam.

Al-Qur'an dan al-Hadits merupakan dua asas penting yang menjadi basis keilmuan yang akan memunculkan ilmu-ilmu keislaman. Keduanya dapat bermakna dan memiliki nilai keilmuan, ketika diletakkan bersama-sama dengan akal, dilakukan observasi, eksperimentasi dan seperangkat metodologi lainnya. Dari proses itulah, akan melahirkan ilmuilmu alam dan ilmu-ilmu sosial. Lebihlebih jika dilakukan secara beriringan dan serempak, maka akan melahirkan bidang-bidang keilmuan alam, sosial, dan humaniora.

Pada aras ini, Al-Qur'an dan al-Hadits akan memancarkan sinar pengetahuannya dan diyakini sebagai pemberi kepastian tanpa ragu. Implikasinya adalah terjadinya sinergi yang harmonis, antara wahyu dan akal dalam kerangka kerja ilmiah. Keduanya akan saling melengkapi dan saling memberikan masukan dengan tetap berpijak pada dasar moralitas yang kuat dan mutlak kebenarannya. Konsep inilah, yang kemudian menjadi upaya peting bagi lahirnya kesatuan pengetahuan. Kesatuan yang bersumber dari Yang Maha Esa.

Oleh sebab itu, maka tiada alasan untuk dengan mudah mencoba memisahkan ilmu umum yang dianggap sekuler oleh sebagian orang (seperti ilmu sains dan ilmu sosial humaniora dengan berbagai cabangnya). Karena dengan adanya petunjuk al-Qur'ân yang merupakan asas atau dasar orang yang beragama Islam, seorang ilmuan akan memperoleh inspirasi bagi penemuanpenemuan ilmiah lainnya. Meskipun AlQur'ân bukanlah kitab ilmu pengetahuan, namun ia memuat berbagai isyarat kepada manusia untuk mengadakan penelitian ilmiah dan mengembangkan berbagai disiplin ilmu pengetahuan, sebagaimana Firman Allah dalam surat Yûnus, ayat 101 berikut: "Perhatikanlah terhadap apa yang ada di langit dan di bumi, tidaklah bermanfaat tanda kekuasaan Allah dan rasul-rasul yang memberi peringatan bagi orang-orang yang tidak beriman".

\section{Itegrasi-Interkoneksi; Integrasi Keilmuan UIN Yogyakarta}

Mengkaji tentang paradigma keilmuan di Universitas Islam Negeri Sunan Kalijaga Yogyakarta, tidak lepas dari sosok Prof. Amin Abdullah, ${ }^{29}$ mantan Rektor sekaligus perumus tentang proyek integrasi-interkoneksi keilmuan di universitas ini. Beliau adalah salah satu sosok yang paling otoritatif dalam membincangkan persoalan integrasi ilmu agama dan sains di Indonesia. Sehingga, ketika bicara tentang paradigma integrasi keilmuan di UIN Yogyakarta, maka tak akan lepas dari pemikiran beliau.

Proyek integrasi keilmuan di UIN Sunan Kalijaga sudah berlangsung lama, jika dihitung dari awal berdirinya, yaitu padatahun 2004 hinggahariinitahun2019, maka 15 tahun sudah proyek integrasi keilmuan telah diimplementasikan dan diinternalisasikan. Konsep integrasi yang dibangun adalah Integrasi-Interkoneksi ilmu. Untuk menggali lebih luas, konsep ini kemudian dituangkan kedalam sebuah naskah akademik, yang memandu para civitas academika UIN Yogyakarta, untuk menerapkan nilai-nilai integrasi

29 Amin Abdullah lahir pada tanggal 28 Juli 1953, di daerah Margomulyo, Tayu, Pati, Jawa Tengah. Sekolah menengah dihabiskan di Pesantren Gontor, Ponorogo, dan lulus pada tahun 1972. Kemudian pada tahun 1981, beliau menyelesaikan S1 pada Jurusan Perbandingan Agama Fakultas Ushuluddin, IAIN Yogyakarta. Pada tahun 1985, memperoleh beasiswa untuk melanjutkan program Ph.D di Turki. Beliau mengambil konsentrasi Filsafat Islam, Department of Philosophy, the Faculty of Art and Sciences, Middle East Technical University (METU), Ankara, Turki. Beliau menyelesaikan program ini pada tahun 1990, dengan menulis disertasi "The Idea of Universality of Ethical Norms in Ghazali and Kant", diterbitkan di Turki (Ankara: Turkiye Diyanet Vakfi, 1992) 
di lapangan. Konsep tersebut, termaktub dalam buku Kerangka Dasar Keilmuan dan Kurikulum UIN Sunan Kalijaga Yogyakarta, yang diterbikan pada tahun 2004.

Secara filosofis, konsep integrasi keilmuan yang dibangun oleh Amin Abdullah di UIN Yogyakarta, secara spesifik dapat dilihat pada metafora Jaring Laba-laba. Metafora ini, memberikan gambaran penting tentang bagaimana proses pengkajian dalam studi keislaman sudah berkembang dan melakukan pengembangan pada masa yang akan datang dengan integrasi keilmuan. Gagasan ini, merupakan refleksi atas perbagai persoalan kontemporer yang saat ini dihadapi oleh umat Islam. Mulai dari persoalan teknologi yang telah membuka lebar perjumpaan antar bangsa dan antar budaya, problem migrasi, HAM, genetika, persoalan gender, dan lain sebagainya. Persoalan itu, menuntut perubahan pula pada kajian keislaman di perguruan Tinggi Agama Islam. Jika umat Islam tidak mampu merespon persoalanpersoalan global tersebut, maka jangan heran jika kemudian kaum muslimin semakin tertinggal jauh oleh Barat. Umat Islam lebih banyak menjadi penonton saja, dari pada menjadi pelaku. dan hanya menyaksikan terhadap perubahan itu sendiri. Menghadapi tantangan itu, Islam harus lah menjadi garda terdepan dalam menghadapi perubahan tersebut.

Oleh karena itu, dibutuhkan sebuah reorientasi keilmuan dan rekonstruksi sistem kelembagaan. Dikotomisasi antara ilmu umum dan ilmu agama yang selama ini menggelayut pada keilmuan keislaman, telah memperburuk hubungan atau memperlebar jurang pemisah antara ilmuan umum dengan ilmuan agama (ulama), antara riset-riset ilmiah berbasis sains dan riset-riset berbasis keagamaan. Islam sebagai ilmu, yang menggiring umatnya untuk mempelajari ilmu, justru hanya menjadi ungkapan semata. Maka tawaran akan pentingnya paradigma integratif-interkonektif menjadi sebuah "pengibat" bagi upaya untuk menggeser ketegangan-ketegangan tersebut, tanpa harus meleburkan satu sama lainnya.

Paradigma integratif-interkoneksi adalah konsep keilmuan yang berusaha mendekatkan, mengkoneksikan, dan mengaitkan antara ilmu kealaman, ilmu keagamaan, dan ilmu humaniora, sehingga ketiganya menjadi saling "bertegur sapa" satu sama lain. Secara implementatif, paradigma ini dapat dilihat dalam pola kerja sebagai berikut, yaitu Pertama, mempertemukan ilmu keagamaan(Islam)denganilmukealaman. Atau Kedua, mempertemukan ilmu keaagamaan (Islam) dengan ilmu sosial humaniora. Atau Ketiga, mempertemukan ilmu kealaman dengan ilmu-ilmu sosial humaniora. ${ }^{30}$ Tentu, yang terbaik diantara ketiganya adalah upaya mempertemukan ketiga disiplin keilmuan tersebut. Dengan adanya upaya menjalinkelindakan atau memberikan ruang bagi adanya interaksi yang terus menerus, ketiga disiplin keilmuan tersebut, maka justru akan memperkuat satu sama lainnya, bukan saling melemahkan, sehingga kontruksi epistemologis masing-masing keilmuan akan \semakin kuat dan kokoh.

Berikut adalah gambar kontruksi paradigma keilmuan integratifinterkonektif, yang telah digambarkan sebagai "spider web" atau jaring laba-laba keilmuan. Ilustrasi pada metafora jaring laba-laba ini, mempertegas akan corak teoantroposentris-integralistik-interkonektif. Secara ilustratif, pola kerja dari jaring labalaba keilmuan ini adalah bahwa al-Qur'an dan al-Sunnah merupakan basis penting bagi bangunan keilmuan. Dari sini, lalu berkembang dan diupayakan melalui kerja-kerja riset, dengan menggunakan berbagai metode dan pendekatan. Proses selanjutnya adalah al-Qur'an dan al-

$30 \quad$ Abu Darda, "Integrasi Ilmu dan Agama: Perkembangan Konseptual di Indonesia" dalam Jurnal Jurnal AtTa'dib Vol. 10. No. 1, Juni 2015, hlm. 42 
Sunnah kemudian menjadi pendorong bagi munculnya disiplin ilmu-ilmu baru pada setiap lapisan selanjutnya. Begitulah seterusnya, melalui berbagai pendekatan dan metode, maka jaring laba-laba dapat melahirkan ilmu sosial-humaniora, kealaman, dan ilmu kontemporer lainnya, dengan tetap berbasis dari al-Qur'an dan al-Hadits. Sebagaimana terekam pada gambar:
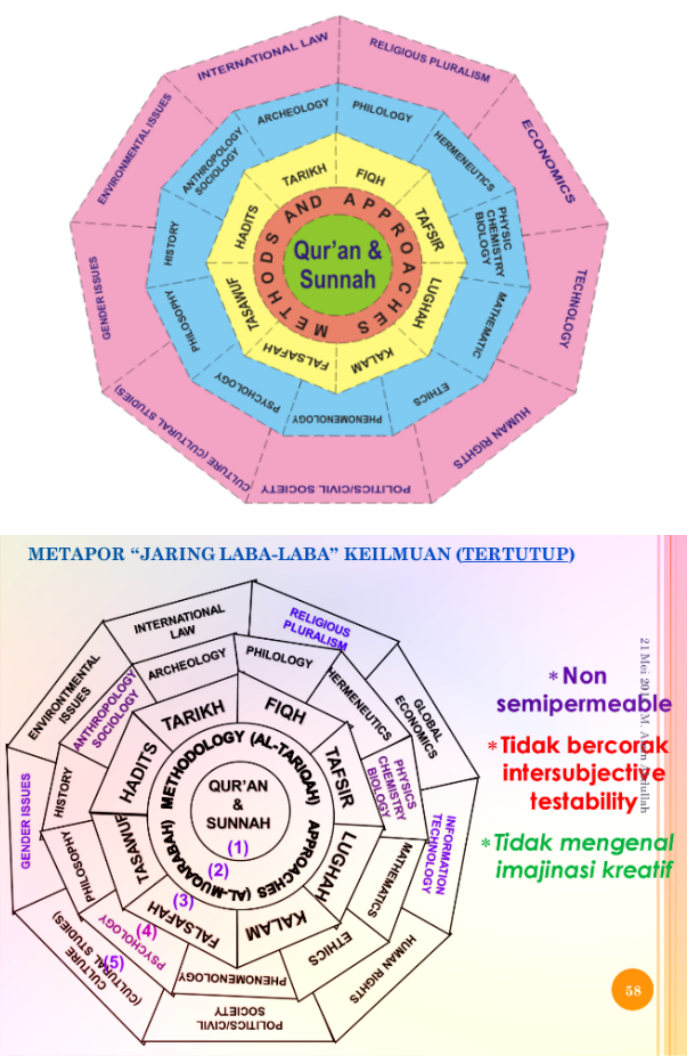

Jaring Labalaba UIN SUKA Yogyakarta

Pada gambar di atas, terdapat garis putus-putus yang memiliki kemiripan dengan pori-pori. Garis itu melekat pada setiap dinding yang membatasi antar disiplin ilmu yang ada. Hal ini, memberikan makna bahwa setiap disiplin ilmu tidak saja merupakan proses pembidangan yang menjadi area disiplin ilmu itu sendiri, melainkan menunjukkan bahwa masing-masing disiplin ilmu itu memiliki batas-batas tertentu, ia dibatasi oleh ruang dan waktu (space and time), memiliki corak berpikir (world view) atau metodenya bahkan urf-nya masing- masing disiplin ilmu. Karena memang, masing-masing ilmu memiliki prosedur dan mekanisme serta kebenarannya sendiri-sendiri.

Meskipun masing-masing seolaholah berdiri sendiri, namun ada ruang "dialog" pada ilustrasi tersebut. Yaitu adanya pori-pori yang ada pada dinding (ventilasi). Hal ini, merupakan refleksi akan adanya media sirkulasi untuk mengatur keluar masuknya udara. Hal memberikan makna bahwa sirkulasi keluar-masuknya udara dimaksudkan agar terciptanya saling tukar metodologi dan pendekatan antar disiplin keilmuan yang ada. Dalam proses ini, setiap disiplin ilmu beserta perangkat kerjanya, diasumsikan mulai budaya pikir, tradisi atau 'urf-nya, dapat melakukan komunikasi, saling berjalin kelindan, dan saling bertukar pesan dengan bebas. Titik-titik lubang pada jaring laba-laba itu, menghendakai akan adanya saling isi antar bidang keilmuan. Sehingga akan diperoleh jejaring informasi, saling timbal bailk, dalam suasana yang bebas, nyaman dan tanpa adanya beban. ${ }^{31}$

Dengan demikian, disatu sisi setiap disiplin ilmu tetap eksis dengan identitasnya masing-masing, tanpa harus melebur pada disiplin ilmu lainnya, namun tidak menutup kemungkinan untuk terjadinya proses dialog, selalu terbuka, saling berkoneksi, berkomunikasi, dan berdiskusi dengan disiplin ilmu lainnya. Dalam proses ini, tidak ada lagi sebuah disiplin ilmu berdiri sendiri dengan "angkuh", melainkan harus bersedia dirembesi atau dimasuki oleh disiplin ilmu lain. Ini lah harapan besar yang dibangun oleh Amin Abdullah, sebagaimana yang di kemukakan sebagai berikut:

Struktur keilmuan itu telah membawa harapan baru terhadap cara pandang

\footnotetext{
31 M. Amin Abdullah, "Religion, Science and Culture; An Integrated, Interconnected Paradigm of Science", Al-Jami'ah, Vol. 52, No. 1, 2014 M/1435 H, hlm. 182.
} 
keilmuan yang tidak lagi bersifat myopic, tetapi lebih luas dan komprehensif, sekaligus terampil dalam perikehidupan sektor tradisional maupun modern lantaran dikuasainya ilmu dasar dan keterampilan yang dapat menopang kehidupan era informasi-globalisasi. Di samping itu tergambar sosok manusia yang terampil dalam menangani dan menganalisis isu-isu yang menyentuh kemanusiaan dan keagamaan era modern serta pascamodern dengan dikuasainya berbagai pendekatan baru yang diberikan oleh ilmu-ilmu alam, ilmu-ilmu sosial dan humaniora kontemporer. ${ }^{32}$

Pada akhirnya, kedepan perangkat kerja semua disiplin ilmu pengetahuan, tidak lagi berdiri sendiri-sendiri. Lebih-lebih melihat problem-problem kemanusiaan hari ini yang semakin banyak, maka masing-masing disiplin ilmu harus berani membuka diri untuk selalu membekali diri dengan perangkat lunak supaya mampu saling menjaga, memelihara, dan mengawasi antar disiplin ilmu. Dengan proses ini, maka kesediaan untuk terbuka, berdialog, saling tukar informasi, menjadi sangat penting untuk dilakukan.

\section{Pohon Keilmuan; Integrasi Keilmuan UIN Maliki Malang}

Jika di UIN Yogyakarta ada Amin Abdullah, maka di UIN Malang juga ada Imam Suprayogo. ${ }^{33}$ Seorang ahli strategi pengembangan kelembagaan yang sangat mumpuni. Banyak lembaga pendidikan yang melalui sentuhan tangan beliau, langsung top cer. Lihat misalnya

32 M. Amin Abdullah, "New Horizon of Islamic Studies Through Socio-Cultural Hermeneutics," dalam AlJami'ah: Journal of Islamic Studies, Vol. 41, No. 1, 2003/1424, hlm. 16-19.

33 Prof. Dr. Imam Suprayogo, M.Si, lahir pada tanggal 02 januari 1951 di Trenggalek, Jawa Timur. Beliau menghabiskan masa pendidikan dasar, menengah pertama, dan menengah atas di tempat kelahirannya. Kemudian beliau meneruskan pendidikan S1 pada Fakultas Tarbiyah, IAIN Malang. Selanjutnya program Doktor ditempuhnya pada bidang Ilmu Sosial dan Ilmu Politik di Universitas Airlangga (UNAIR) Surabaya.
Universitas Muhammadiyah Malang (UMM), bersama Prof. Malik Fadjar, telah dirubah menjadi universitas paling bergengsi secara nasional. Kemudian UIN Malang sendiri dengan sentuhan managerialnya, telah berdiri megah dari yang semula STAIN.

Secara konseptual, proses pengembangan paradigma integrasi keilmuan yang dilakukan oleh UIN Malang adalah mengembangkan basis keilmuan dengan metafora "pohon ilmu". Artinya, filsafat ilmu dan pondasi keilmuannya adalah digambarkan dengan "Pohon Ilmu". Menurut Imam Suprayogo, argumentasi sederhana mengenai pohon keilmuan ini adalah bahwa:

“....pada sebatang pohon, selalu terbayang pada dirinya, terdapat sebuah keindahan, dan sangat tepat digunakan untuk menerangkan tentang integrasi antara ilmu-ilmu agama dan ilmu-ilmu umum. Pohon tumbuh dalam waktu lama, bertahuntahun, bahkan beberapa jenis tertentu usianya melebihi usia manusia. Kehidupan dan pertumbuhan pohon juga dapat untuk menggambarkan, bahwa ilmu juga selalu tumbuh dan berkembang..." 34

Pohon yang tumbuh subur, maka selain ia akan lebat dan rindang, juga akan tumbuh berkembang dengan cepat. Pohon yang subur, juga akan memperkuat dan memperkokoh akar. Dengan akar yang kokoh dan kuat, maka batang pohon pun akan berdiri dengan kuat dan kokoh. Jika pohon telah tumbuh subur dan kokoh, maka akan menghasilkan buah yang sehat dan manis pula. Tanah merupakan tempat di mana pohon itu tumbuh. Dalam konteks akademik, lingkungan dan budayanya sangat perlu perawatan

34 Imam Suprayogo,. Paradigma Pengembangan Keilmuan di Perguruan Tinggi. (Malang: UIN Malang Press, 2009), 
dan penumbuh-suburan secara terus menerus. Meskipun tanah dan pohon adalah dua entitas yang berbeda, namun keduanya pada hakikatnya membawa misi yang sama, yaitu mensejahterakan dan membahagiakan seluruh umat manusia.

Itulah dasar-dasar umum tentang makna filosofis "pohon ilmu". Kontruksi pemahaman tentang "pohon", sebagaimana yang kita pahami bersama sebagai sebuah pohon pada umumnya. Ada akar, batang-tubuh, ranting, dan dahan. Masing-masing memiliki fungsi dan cara kerja yang berbeda-beda, namun memiliki keterkaitan satu sama lain. Mereka tidak berdiri sendiri. Bahkan mereka saling bantu-membantu, saling terbuka, berjalin-kelindan antar bagian, demi terwujudnya pohon yang subur dan kokoh. Berikut adalah gambaran integrasi ilmu yang dikembangkan oleh UIN Maliki Malang. Di Kampus, metafora ini di gambar indah di lantai I, Rektorat UIN Maliki Malang.

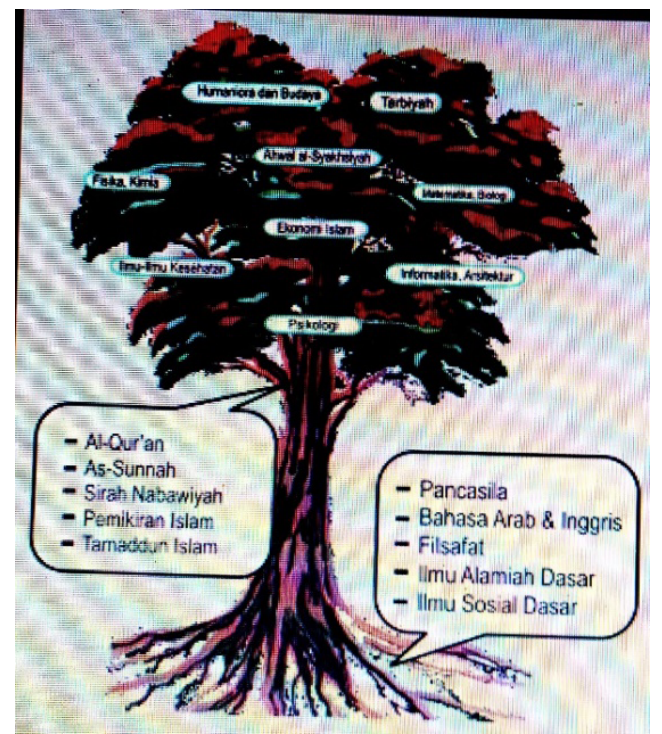

Gambar di atas, memiliki makna sebagai berikut;

a. Seorang sarjana perlu dibekali dan diperkuat dengan seperangkat ilmuilmu dasar atau ilmu pengetahuan instrumental; misalnya kemampuan berbahasa, baik berbahasa Indonesia, Arab, dan Inggris; ilmu logika, filsafat ilmu, ilmu dasar kealaman dan ilmu dasar sosial. Dalam gambar tersebut, seperangkat keilmuan tersebut, merupakan akar dari pohon. Agar pohon tidak mudah roboh, maka akarnya harus kuat dan kokoh. Artinya, semakin bagus dasar keilmuan tersebut dimiliki oleh seorang sarjana, maka ia akan memiliki peluang untuk mampu mengembangkan dan memahami batang pohon.

b. Batang pohon digambarkan dengan seperangkat keilmuan yang bersumber langsung dari ilmu-ilmu Islam (dirasah al-Islamiyah), yaitu alQur'an dan Hadits, pemikiran Islam, dan sejarah Nabi Muhammad, serta sejarah peradaban Islam. Seorang sarjana yang baik, tidak mungkin bisa membesarkan batang pohon, jika ia tidak memiliki kemampuan sebagaimana tergambar pada akar pohon di atas. Dengan akar yang kokoh, maka ia akan menumbuhbesarkan batang pohon yang kokoh pula. Jika batang bagus dan kokoh, maka akan memunculkan cabang dan ranting serta dedaunan yang indah dan segar.

c. Nah, cabang dan ranting serta dedaunan dalam gambar di atas adalah ilmu-ilmu modern; seperti ilmu kedokteran, filsafat, psikologi, ekonomi, sosiologi, teknik serta cabang-cabangilmulainnya. Disinilah setiap mahasiswa diwajibkan untuk memilih dan memiliki kemampuan salah satu dari cabang keilmuan ini. Kekuatan cabang dan ranting serta daun ini, terekspresi pada kekuatan dan kesuburan akar dan batang pohon. ${ }^{35}$

35 Imam Suprayogo, "Mereformasi Bangunan Keilmuan di Perguruan Tinggi Islam", http:// old.uin-malang.ac.id/index.php?option $=\mathrm{com}_{-}$ content\&vi ew =article \& id=441:19-07- 
Adapun sisi integrasi dari metafora di atas, terlihat dari antara bagian-bagian pohon itu. Meskipun terlihat masingmasing berdiri sendiri-sendiri antara berbagai bagian, misalnya antara akar dengan batang; ranting dengan dahan, namun demikian bukankah proses pertumbuhannya serentak? Satu sama lain saling mengisi dan bergerak untuk tumbuh, karena pada dasarnya tumbuhan tersebut, berasal dari ranting dan batang yang sama. Dengan dasar ini, seluruh civitas akademica, yaitu para dosen dan mahasiswa secara intensif dan kontinu, terus mengkaji dan memahami al-Qur'an, hadis, dan alam raya, secara bersama dan seiring sejalan. ${ }^{36}$

Implikasi lain dari paradigma tersebut adalah, keharusan semua civitas akademika untuk memiliki kemampuan berbahasa asing, Arab atau Inggris. Gagasan tentang pentingnya Ma'had Aly (Pondok Pesantren tingkat Tinggi), pendidikan Tinggi dengan sistem Pesantren juga dimulai oleh UIN Malang ini, yang kemudian diikuti oleh seluruh UIN di Indonesia. Fungsi utama dari adanya Ma'had Aly ini adalah untuk menumbuhkembangkan atau mentradisikan secara ajeg, komunikasi antar mahasiswa yang tinggal di asrama untuk berbahasa asing. Selain mengkaji ilmu-ilmu keislaman lainnya. Dilingkungan UIN Malang, Ma'had Aly dibangun secara integratif dengan asrama dan Masjid, hal ini ditujukan agar tercipta kekuatan kultural dan akademik dalam proses pendidikan Islam.

Dengan adanya pesantren mahasiswa ini, mahasiswa akan dibiasakan dengan berbagai aktivitas selayaknya pesantren. Hal ini didasarkan pada kenyataan bahwa lulusan pesantren lebih mapan dalam memainkan peran-peran keagamaan di masyarakat, dibanding alumni perguruan

2008\&catid=25:artikel-imam-suprayogo,.

36 Prof. DR. H. Imam Suprayogo. Pohon Ilmu UIN

Malang. https://tulisanterkini.com/artikel /keislaman/ umum/5575-pohon-ilmu-uin-maliki-malang-.html tinggi. Hal itulah, yang memperkuat pentingnya model pesantren di UIN Malang, karena selain proses transformasi keilmuan di perguruan Tinggi, maka dengan pondok pesantren yang bagus, akan dapat mengembangkan kultur keilmuan yang baik pula.

\section{PENUTUP}

Eksistensi suatu universitas dapat direfleksikan secara aktual dari kondisi sumberdaya manusia (SDM) dan kajiannya yang berada di universitas dengan yang lain secara universal. Dan tantangan terbesar dari universitas Islam di negeri ini, justru berada pada dua wilayah ini. Namun demikian, kemunculan UIN di negeri ini, setidaknya telah memiliki konsep epistemologis yang sudah ada, sehingga akan mempermudah bagi pengelolanya untuk mengaktualisasikannya dalam bentuk yang lebih universal. Sebagai sebuah lembaga pendidikan Islam, maka Al-Qur'an dan Al-Hadits menjadi sangat penting untuk dijadikan landasan dalam penyelenggaraan proses pendidikan dan penelitan. Pada proses ini, maka Al-Qur'an dan Al-Hadits tidak lagi digunakan hanya sebatas pada paradigma atau sebagai frame of reference, misalnya hanya pada tataran ibadah saja, namun Al-Qur'an dan AlHadits harus dipahami sebagai media informasi hakiki dan transendental.

Dari bahasan ini, dapat diketahui bahwa model pengembangan paradigma "integrasi ilmu" yang dikembangkan UIN Yogyakarta dengan simbol "Jaring laba-laba ilmu"dan UIN Maliki Malang dengan paradigma "pohon ilmu", terdapat persamanaan dalam hal : (1) menjadikan Al-Qur'an dan Al-Hadits sebagai sumber ilmu pengetahuan, (2) memperluas materi kajian Agama Islam dan menghindari dikotomi ilmu, (3) menelusuri ayat-ayat al-Quran yang berbicara tentang sains, 4) mengembangkan kurikulum pendidikan; telah menjadi inspirasi dan rujukan 
bagi PTKI di seluruh Indonesia dalam yang dimiliki UIN Yogyakarta terlihat mengintegrasikan Islam dan Sains pada lebih mapan dan kuat, dari pada UIN berbagai displin ilmu serta penelitian. Malang yang cenderung lebih aplikatif. Namun demikian, landasan epistemologis

\section{DAFTAR PUSTAKA}

Abd.Rachman Assegaf, Studi Islam Kontekstual, (Gema Media,Yogyakarta, 2005)

Abdullah Idi dan Toto Suharto, Revitalisasi Pendidikan Islam. Yogyakarta: Tiara Wacana. 2006)

Abuddin Nata, Manajemen Pendidikan, Mengatasi Kelemahan Pendidikan Islam di Indonesia, (Jakarta: Kencana Prenada Media Group, cet. IV. 2013)

Akh. Minhaji, Tradisi Akademik di Perguruan Tinggi. (Yogyakarta: SUKA Press, 2013)

Daud Rasyid, Islam dalam Berbagai Dimensi, (Bandung: Gema Insani, 1998)

Hadari Nawawi, Hakikat Manusia menurut Islam, (Bandung: Gema Risalah, 1992).

Haidar Putra Daulay, Pemberdayaan Pendidikan Islam di Indonesia, (Jakarta: Rineka Cipta, 2009)

Haidar Putra Daulay, Sejarah Pertumbuhan dan Pembaharuan Pendidikan di Indonesia, (Jakarta: Kencana, 2009)

Imam Suprayogo, Perubahan Pendidikan Tinggi Islam; Refleksi Perubahan IAIN/STAIN menjadi UIN. (Malang: UIN Malang Press. 2008) , Universitas Islam Unggul, (Malang: UIN Malang Press, 2009)

Malang Press, 2009)

. Paradigma Pengembangan Keilmuan di Perguruan Tinggi. (Malang: UIN

Juan E. Campo, Ensyclopedia of Islam. (New York: An Imprint of Infobase Publishing, 2009)

Kuntowijoyo, Islam Sebagai Ilmu Epistimologi, Metodologi dan Etika, (Yogyakarta : Tiara Wacana, 2006)

Marwan Saridjo. Pendidikan Islam dari Masa ke Masa: Tinjauan Kebijakan Publik terhadap Pendidikan Islam di Indonesia, (Bogor: Yayasan Ngali Aksara dan alManar Press, Cet. II. 2011)

Moh. Raqib, Ilmu Pendidikan Islam, Pengembangan Pendidikan Integratif di Sekolah, Keluarga, dan Masyarakat, (Yokyakarta: LKiS, 2009)

Syamsul Arifin dkk, Spiritualisasi Islam dan Peradaban Masa Depan, (Yogyakarta: SIPRESS, 1996)

Syed Muhammad Naquib al-Attas, Islam and Secularism, (Kuala Lumpur: ISTAC, Edisi Kedua, 1993)

Taufik Abdullah dkk, (ed)., Ensiklopedi Tematis Dunia Islam, jilid ke-6, (Jakarta: Ichtiar Baru Van Hoeve, 2002.

W.J.S. Poerdowasminto, Konsosrsium Bahasa Indonesia, (Jakarta : Balai Pustaka, 1986)

Zainal Abidin Bagir, dkk., (Eds)., Integrasi Ilmu dan Agama: Intrepretasi dan Aksi. (Bandung: PT Mizan Pustaka Kerjasama dengan UGM dan Suka Press Yogyakarta, 2005). 
Zainal Habib, Islamisasi Sains. (Malang, UIN Malang Press, 2007)

Abu Darda, "Integrasi Ilmu dan Agama: Perkembangan Konseptual di Indonesia" dalam Jurnal Jurnal At-Ta'dib Vol. 10. No. 1, Juni 2015,

Laily Nur Arifa, "PERUBAHAN STAIN/IAIN MENJADI UIN SEBAGAI BENTUK PENGEMBANGAN PENDIDIKAN TINGGI ISLAM (Contoh Kasus Perubahan STAIN menjadi UIN Malang Perspektif Manajemen Perubahan Kurt Lewin)" dalam Jurnal Vicratina Vol 01, No 2 (2017).

Muljono Damopolii, "Potret Pendidikan Islam: Perspektif Pembaruan Pemikiran Dan Gerakan Islam Indonesia Kontemporer" dalam Jurnal Lentera Pendidikan, Edisi X, no. 1, Juni 2007

M. Amin Abdullah, "Religion, Science and Culture; An Integrated, Interconnected Paradigm of Science", Al-Jami'ah, Vol. 52, No. 1, 2014 M/1435 H

M. Amin Abdullah, "New Horizon of Islamic Studies Through Socio-Cultural Hermeneutics," dalam Al-Jami'ah: Journal of Islamic Studies, Vol. 41, No. 1, 2003/1424

Imam Suprayogo, "Mereformasi Bangunan Keilmuan di Perguruan Tinggi Islam", http:// old.uin-malang.ac.id/index.php?option=com_content\&view=article\&id=441:1907-2008\&catid=25:artikel-imam-suprayogo,

Imam Suprayogo. Pohon Ilmu UIN Malang. https://tulisanterkini.com/artikel / keislaman/umum/5575-pohon-ilmu-uin-maliki-malang-.html

M. Amir Ali, Removing The Dichotomy of Science : ANecessity for The Growth of Muslims. future Islam " A Journal of Future Ideology that Shapes Today The World Tomorrow. http"//www. futureislam. com/ 20050301/insight. 